\title{
Model of Jogo Tonggo's Alert Village in Suppressing the Distribution of Covid-19 in the New Normal Era
}

\author{
Yudha Radistyo ${ }^{1, *}$ Dimas Julianto ${ }^{2}$ Handika Mukti $^{3}$ \\ ${ }^{1,2,3}$ Fakultas Ilmu Sosial, Universitas Negeri Semarang \\ *Corresponding author. Email: yudharadistyo@students.unnes.ac.id
}

\begin{abstract}
Data from the Central Java Provincial Health Office noted that on July 15, 2020 there were 543 people died due to coronavirus disease 2019 (covid-19). The Central Java government adopted the policy of the jogo tonggo program to reduce the spread figures. Jogo tonggo is an accelerated policy of handling community-based Covid-19 at the Citizen House level. Jomblang Village is implementing the jogo tonggo program by mobilizing community participation. This study aims to determine the implementation of the Jogo Tonggo model in suppressing covid-19 growth rates in Jomblang Village. The study was conducted by collecting data in the field and analyzing field findings with inductive thinking logic. Based on this implementation, this research uses qualitative methods with interview, observation and documentation techniques as well as using related literature studies. This study examines the implementation of the Jogo Tonggo model in suppressing the covid-19 growth rate in Jomblang Village. The existence of this research can enrich scientific studies and become literature to apply the Jogo Tonggo model in suppressing the growth rate of covid- 19 .
\end{abstract}

Keywords : Covid-19, Jogo Tonggo.

\section{INTRODUCTION}

In early-2020, the world was shocked by the outbreak of a new pneumonia that started in Wuhan, Hubei Province and then spread rapidly to more than 190 countries and territories. This outbreak is named Coronavirus Disease 2019 (COVID-19) which is caused by Severe Acute Respiratory Syndrome Coronavirus-2 (SARS-CoV-2020). According to the World Health Organization, Coronavirus (COVID-19) is an infectious disease caused by a new type of virus that has never been identified in humans. The first COVID-19 was reported in Indonesia on March 2, 2020, totaling two cases. March 31, 2020 data shows that there are 1,528 confirmed cases and 136 deaths. 0 The mortality rate for COVID-19 in Indonesia is $8.9 \%$, this figure is the highest in Southeast Asia. With the high mortality rate in Indonesia, the government and political elites must take swift action to break the spread of the Covid-19 chain. The government has declared a Covid-19 emergency status and is actively giving an appeal to limit social interactions to reduce the spread of the pandemic. Existing forms of restrictions include limiting the quota for public transportation passengers to prohibiting all types of joint worship activities. In addition, he also created a mapping of sufferers who were grouped by region through the official online government website.

To break the chain of spreading the covid-19 virus, the government urges you to stay at home. Recently, the term new normal or new normal has appeared. The new normal order is intended so that the economy in the country can recover. According to Yuri (in the Ministry of Health), new arrangements, habits and behaviors based on adaptation to cultivate a clean and healthy lifestyle are then called new normal. The method is to routinely wash hands with soap, wear a mask when leaving the house, keep a safe distance and avoid crowds. He hopes that this new habit must become a collective awareness so that it can run well[3].

The addition of Covid-19 cases that have spread in 34 provinces in Indonesia, including Central Java Province which is in 5th position with the number of Covid-19 cases as of 30 May 2020 reaching 1,434 cases, 759 people recovered and 97 people died. Meanwhile, the number of People Under Monitoring (ODP) related to Covid-19 in Central Java reached 35,450. Almost all 
districts in Central Java Province are exposed to Covid19, including Semarang City 63 cases, Magelang 77 cases, Purworejo 37 cases, Wonosobo 19 cases, Banyumas 19 cases, Purbalingga 25 cases, Temanggung 26 cases, Cilacap 20 cases, Demak 18 cases , Banjarnegara 24 cases, Sukoharjo 12 cases, Salatiga 24 cases, Surakarta 8 cases, Kudus 3 cases, Brebes 26 cases, Sragen 20 cases, Karanganyar 6 cases, Pemalang 5 cases, Kebumen 6 cases, Batang 19 cases, Semarang Regency 9 cases, Boyolali 11 cases, Blora 21 cases, Magelang City 7 cases, Pati 1 positive case and 73 ODP, Klaten positive 7 cases and 153 ODP cases, Grobogan 5 cases, Tegal 2 cases, Jepara 9 cases, Pekalongan 5 cases, Pekalongan City 4 cases, Wonogiri 0 positive and ODP 61 people, Kendal 2 cases, Rembang 2 cases, Tegal City 0 positive and ODP 10 people. Of all districts in Central Java Province, Magelang Regency occupies the first position in the regency that has the most Covid-19 exposure[6].

By observing the development of the Covid-19 case in every Regency / City in Central Java Province every day which is always increasing, therefore efforts are needed to overcome it. In this case, what policies have been issued by the Central Java Provincial Government to deal with the Covid-19 outbreak. One of the Central Java Government policies in overcoming Covid-19 is Jogo Tonggo. The Jogo Tonggo alert village model is a community-based model for accelerating the handling of the community-based pandemic COVID-19 pandemic set in Central Java. Jogo is a phrase in Javanese which means guarding or guarding, and tonggo means neighbor, which means taking care of each other. The consideration is that it is the community who is directly dealing with the transmission of Covid-19, so prevention must place them as the joint front guard. always supportive government. The concept is implemented at the Rukun Warga (RW) level which involves the community directly to take care of neighbors who are affected by the outbreak, are exposed to the corona virus, and are directly affected economically. In several districts and cities, Jogo Tonggo was an alternative choice before the PSBB policy was implemented, because this would have a more complicated[2].

Jomblang Village, especially RW 5, Candisari District, one of the villages in the city of Semarang, is implementing the Jogo Tonggo alert village model as a step to handle the Covid-19 pandemic. The Jogo Tonggo program was implemented according to Pak Ganjar Pranowo's orders in dealing with Covid-19. All criteria have been met, starting from safety, economy, entertainment and health. The residents use the RW hall to implement the program. Communities who are able to help each other, and assistance from all parties are accommodated together and then distributed to residents in need.

Based on this description, this research is intended to determine the Jogo Tonggo standby village model implemented by Jomblang Village RW 5, Candisari District, Semarang City. This research has problem formulation 1. How is the Jogo Tonggo alert village model implemented by Jomblang Village, Candisari District, Semarang City. 2. How does the community respond to the Jogo Tonggo village alert model policy in dealing with the Covid-19 pandemic. Based on the formulation of the problem, this study aims to: 1 . To find out how the Jogo Tonggo alert village model is implemented in Jomblang Village, Candisari District, Semarang City. 2. To find out the public's response to the Jogo Tonggo village alert model policy in dealing with the Covid-19 pandemic. Therefore, the researcher raised the research with the title "Jogo Tonggo Alert Village Model in Suppressing the Spread of Covid-19 in the New Normal Era".

\section{METHODOLOGY}

This study uses a descriptive qualitative approach with data collection methods through observation, interviews, and literature study. Researchers went directly to the field to conduct in-depth interviews with informants who could support data collection on the jogo tonggo alert village model in suppressing the spread of Covid-19 in the new normal era. The data was accessed using three research tools, namely; online interviews, observations, and analyzes obtained from searching for news on television, online media, and social media (documentation) to further investigate the phenomena that occur. Online interviews were conducted through social media; Whatsapp, Instragram, and Facebook for several members of the community who have different work, education and living backgrounds. The reason the researcher uses this qualitative approach is to obtain data that can explain the situation clearly and in detail at the research site. Research using a qualitative approach intends to understand the phenomena experienced by research subjects.

The research subjects in this study were the people of Jomblang Village RW 5, Candisari District, Semarang City. This is because the focus in this study is the Jogo Tonggo village model in Jomblang Village. The consideration of informants in this study is to obtain data in completing research information. The informants in this study have indicators; 1). People who live in Jomblang Village, Candisari District, Semarang City, 2). And also students. Data analysis was carried out using a qualitative approach and presented descriptively. Data analysis techniques consist of data collection, data 
reduction, data presentation, and decision making or verification.

\section{RESULT AND DISCUSSION}

\subsection{Jogo Tonggo Alert Village Model in Jomblang Village, Candisari District, Semarang City}

The Central Java government has issued a policy for handling Covid-19, namely the Jogo Tonggo policy. The term Jogo Tonggo is taken from the Javanese language. "Jogo" means guarding, while "Tonggo" means neighbor. The Jogo Tonggo policy came into effect on April 25, 2020. Since its formation, the Covid19 outbreak has continued to increase. The government needs to obtain information regarding the description and evaluation of policies that have been issued. The description and evaluation carried out can be used as consideration for choosing actions or alternative policies that can be taken to overcome the problem of the Covid19 outbreak[7].

The policies that have been running so far have not produced good results. The addition of positive cases of Covid-19 in Central Java continues to grow and ranks 5 th out of 34 provinces. The Jogo Tonggo policy has not been fully implemented in the field. There are still many education that the government has socialized to the community, such as crowding, not wearing masks when leaving the house and so on. When Eid al-Fitr approaches, many people leave their homes to shop for their Eid needs. There are still many people who are not aware of the dangers of the Covid-19 outbreak, indicating that there is still a lack of socialization to the public.

Not all regions have a complete Joko Tonggo member. One of them is youth organizations, some areas in Central Java do not have youth organizations, either because they are less active or even passive. So that it will hinder the activeness of the Jogo Tonggo policy itself. But in contrast to RW 5 in Jomblang Village, they already have a Jogo Tongggo policy that is running well, and they also have a structured Jogo Tonggo management.

RW 5 also has a task force in the fields of health, entertainment, economy, and social security. The head of RW 5, Jomblang Driyanto Urban Village, said that the residents work together to run the program. They use the RW hall as a food barn as well as a place to collect data on the community from the economic, artistic, entertainment, social, health and other aspects.

"Program Jogo Tonggo ini kami laksanakan sesuai perintah Pak Gubernur dalam menghadapi Covid19. Kami mencoba memenuhi semua kriteria yang ada, mulai ekonomi, sosial, keamanan, kesehatan dan hiburan," kata Driyanto

Economic programs are used to help people who are experiencing economic difficulties. Meanwhile, for the entertainment program, one of the activities is to optimize the creativity of citizens in the arts and provide entertainment for school children. In the field of social and security, the community is always on guard and reminds us that there are residents gathered. The outsiders who enter are also recorded one by one. In the health sector, officers collect data on vulnerable residents such as the elderly and so on [4].

The Jogo Tonggo Policy, has 10 areas of member structure including:

1. Youth Organization

2. Guesthouse Village

3. Integrated Healthcare Center (Posyandu)

4. Companion PKH

5. PPL (Aagriculture)

6. Village Assistant

7. Other Organizations

8. Public

9. Village Midwife

10. Linmas

Of the ten member fields, they will be the ones who will assist the government in handling Covid-19. In addition, the Jogo Tonggo Policy also has working principles, namely:

1. Humanity

2. Non Permanent, during an emergency

3. mutual cooperation

4. Transparent

5. Involving all parties

The Jogo Tonggo Policy has an Organizational Structure, as follows: 


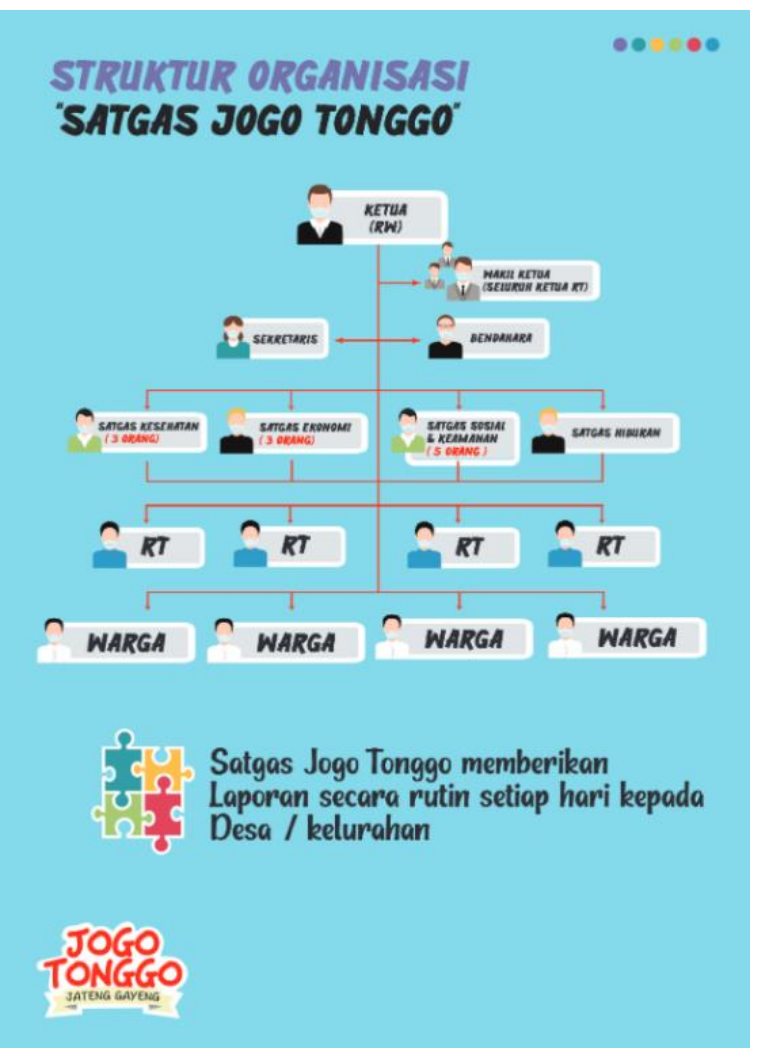

Figure 1. Organizational Structure of the Jogo Tonggo Task Force in Jomblang Village Rw 5 Source: Central Java Public Relations

The Jogo Tonggo Policy has the following duties:

1. Health Sector

a. Record everyone who goes in and out of the village.

b. Prevent the spread and transmission of Covd-19 by bringing people identified as PDP to a referral hospital.

c. Ensure and update only any data with OTG, ODP and PDP status.

d. Strive for ODP and OTG for 14 days selfquarantine.

e. Ensure that the strategic location is available for washing hands, spraying disinfectants regularly, orderly residents leaving the house wearing masks, keeping a distance of 1.5-2 meters between residents

f. Providing health services: checking body temperature, checking Covid-19 symptoms, checking where to wash hands.

g. Encourage the practice of clean and healthy living, balanced eating and drinking, exercise, regular bathing, adequate rest, clean environment.

h. Coordinate with village health officers for further checks in case of emergency.

2. Economy Sector a. List the basic needs of the community

b. List of poor citizens, providing basic needs.

c. Make every effort so that residents can be assisted.

d. Ensuring aid is on target.

e. Ensure farming, gardening and trading activities continue by observing health protocols.

f. Serving the daily needs of residents who are self-quarantined.

g. Encourage the establishment of food barns.

3. Social \& Security Sector

a. Together with the health team, records of people entering and leaving the RW environment.

b. Make a schedule for patrolling turns.

c. Avoid the crowd.

d. Ensuring that with ODP and OTG status do not leave the house.

e. Prepare data for sorting aid recipients so that all assistance is right on target and effective.

f. Ensure that the elderly, disabled, pregnant women and children receive protection.

g. Ensure that all social activities are carried out in mutual cooperation.

h. Reducing and resolving social conflicts through deliberation / deliberation.

i. Ensuring the agreement of residents regarding visiting / visiting hours. $M$

j. Ensure every home has a manual common communication tool.

k. Provide an understanding that the body does not transmit Covid19.

1. Security of food stalls.

4. Entertainment Sector

To reduce boredom, residents can carry out independent entertainment, according to their respective local wisdom. The Jogo Tonggo policy also provides reports regularly every day to villages /sub-districts, such as: residents who are hospitalized, residents recovering from treatment, residents who have and have not received assistance, people who carry out 14-day selfquarantine, the availability of nine staples, visiting hours of residents / guests, patrol schedule, other important information (Central Java Public Relations, 2020).

\subsection{Community Response to the Jogo Tonggo Alert Village Model Policy in Handling the Covid-19 Pandemic}

According to Soekanto (1993: 48) response is a behavior which is a consequence of previous behavior as a response or answer to a particular problem or problem. Meanwhile, Susanto (1998: 73) says that the 
response is a reaction, meaning that it is affirmative or rejection, as well as an indifferent attitude towards what is conveyed by the communicator by the message. Responses can be divided into opinions (opinions) and attitudes, where an opinion or opinion is an open answer (overt) to a problem expressed in spoken or written words. Meanwhile, attitude is a positive or negative reaction to certain people, objects or situations.

According to Syani (1990), the word society comes from the word musyarak (Arabic), which means together then turn into a community, which means gathering together, living together in mutual contact and influencing one another, then getting an agreement to become a community (Indonesia) [1].

Based on some of the above theories, it can be concluded that the community response is a response or answer to a problem or problem given by the community which can be an opinion or attitude. In the Jogo Tonggo village alert model policy carried out at RW 5 Jomblang Village, the community responded positively.

According to Yulio, one of the Unnes students who came from Jomblang Village said that:

"Menurut saya dengan penerapan Jogo Tonggo di Desa Jomblang, khususnya di RW 5 ini memang dapat menekan persebaran Covid-19 ini. Dimana dari RW 5 sendiri sangat minim untuk korban penyebarannya terutama pada pasien maupun orang yang bergejala. Dan juga dari kelurahan sendiri juga mendukung dengan adanya programprogram Jogo Tonggo yang sangat banyak. Karena dengan adanya satgas-satgas perbidang yang memang mengeluarkan program-program yang kreatif dan produktif." (Yulio Kusuma Putra, 21 tahun, mahasiswa, 25 Juli 2020)

The community follows all activities and regulations carried out in Jomblang Village. This response was found from the community because of the qualified implementation of the Jogo Tonggo village alert model. RW 5 Jomblang Village divides the task force into 4 fields, namely social, security, economy, entertainment, and health. In this case, each task force plays an active role. The economic sector is to receive and distribute aid to the community, social and security to protect and avoid crowds and to record people who enter the village, the health sector as a disinfectant spraying scheduler and the entertainment sector holds competitions for children. With the activeness of the community, it can be concluded that there is a good response from the community.

\section{CONCLUSION}

Jogo Tonggo is an activity to reduce the spread of
Covid-19. The Jogo Tonggo alert village model puts forward the principle of taking care of neighbors who have been affected by the outbreak, are exposed to the Covid-19 virus, and are directly affected by the economy. Jomblang Village, one of the villages in the city of Semarang, is implementing the Jogo Tonggo alert village model as a step towards dealing with the Covid-19 pandemic. In this case, Jomblang Village has a task force which is then called the task force which has their respective roles in handling Covid-19. Jomblang Village has 4 task forces, namely: the social and security sector, the economic sector, the health sector and the entertainment sector.

Jomblang Village in suppressing the spread of Covid-19 by applying the jogo alert village model, Tonggo always tries as much as possible to mobilize the community as the front guard in handling Covid-19. Given this, the role of the community is a form of Jogo Tonggo's success. The community responded to the Jogo Tonggo village alert model in a positive way because it directly involved direct participation from the community. Therefore, it is hoped that with the presence of Jogo Tonggo, the suppression of the spread of Covid-19 can be overcome.

\section{REFERENCES}

[1] Anggraini, D. (2016). Interaksi Sosial Orang Tanah Toraja Pada Masyarakat Lokal Di Kabupaten Kolaka. KANAL: Jurnal Ilmu Komunikasi, 2(1), 1. https://doi.org/10.21070/kanal.v2i1.272

[2] Arditama, E., \& Lestari, P. (2020). Jurnal Pendidikan Kewarganegaraan Undiksha Vol. 8 No. 1 (Februari, 2020). Jurnal Pendidikan Kewarganegaraan Undiksha, 8(1), 35-46. https://ejournal.undiksha.ac.id/index.php/JJPP/artic le/view/23548/14372

[3] Biro Komunikasi dan Pelayanan Masyarakat, K. K. R. (2020). Vaksin Covid-19 Belum Ditemukan, Pemerintah Siapkan Skenario New Normal. Www.Kemkes.Go.Id.

https://www.kemkes.go.id/article/view/200529000 01/vaksin-covid-19-belum-ditemukan-pemerintahsiapkan-skenario-new-normal.html

[4] Humas Jateng. (2020a). Ganjar Apresiasi Masyarakat yang Telah Jalankan "Jogo Tonggo." Jatengprov.Go.Id.

https://jatengprov.go.id/publik/ganjar-apresiasimasyarakat-yang-telah-jalankan-jogo-tonggo/

[5] Humas Jateng. (2020b). Percepat Tangani Covid19 dengan "Jogo Tonggo", Apa Itu? Jatengprov.Go.Id.

https://jatengprov.go.id/rilis/percepat-tanganicovid-19-dengan-jogo-tonggo-apa-itu/

[6] Provinsi Jawa Tengah. (2020). Sebaran Kasus 
COVID-19 Di Jawa Tengah. Corona.Jatengprov.Go.Id.

https://corona.jatengprov.go.id/

[7] Sulistiani, K., \& Kaslam. (2020). Kebijakan Jogo
Tonggo Pemerintah Provinsi Jawa Tengah dalam Penanganan Pandemi Covid-19. Vox Populi, 3(1), 31-43. 